\title{
SZEGEDI EGYETEMI HALLGATÓK ISMERETEI A MEGBÍZHATÓ FOGAMZÁSGÁTLÁSRÓL ÉS A SZEXUÁLIS ÚTON TERJEDŐ BETEGSÉGEKRŐL
}

\section{Devosa Iván ${ }^{1}$, Kozinszky Zoltán dr. ${ }^{1,2}$, Vanya Melinda dr. ${ }^{1,3}$, Fáyné Dombi Alice dr. ${ }^{4}$, Barabás Katalin dr. ${ }^{5}$}

${ }^{1}$ Kecskeméti Főiskola Tanítóképző Főiskolai Kar, Egészségtudományi és Egészségfejlesztő Kutató Csoport, Kecskemét, Magyarország

${ }^{2}$ Blekinge Kórház, Szülészeti és Nőgyógyászati Osztály, Karlskrona, Svédország

${ }^{3}$ Szegedi Tudományegyetem, Általános Orvostudományi Kar, Szent-Györgyi Albert Orvosés Gyógyszerésztudományi centrum, Szülészeti- és Nőgyógyászai Klinika, Szeged, Magyarország

${ }^{4}$ Szegedi Tudományegyetem, Juhász Gyula Pedagógusképző Kar, Tanító- és Óvóképző Intézet, Alkalmazott Pedagógia és Pszichológia Tanszék Szeged, Magyarország

${ }^{5}$ Szegedi Tudományegyetem, Általános Orvostudományi Kar, Szent-Györgyi Albert Orvosés Gyógyszerésztudományi centrum, Magatartástudományi Intézet, Szeged, Magyarország

Nyilatkozat: A közlemény más folyóiratban korábban nem jelent meg és más folyóirathoz beküldésre nem került. A levelező szerző elolvasta a szerzői instrukciókat és a kézirat ennek megfelelően került megformázásra.

Anyagi támogatás: A közlemény megírása, illetve a kapcsolódó kutatómunka anyagi támogatásban nem részesült.

Szerzői munkamegosztás: Minden szerző együttesen járult hozzá a kézirat megszövegezésében és az irodalmi áttekintésben stb.; a cikk végleges változatát valamennyi szerző elolvasta és jóváhagyta. 


\section{ÖSSZEFOGLALÁS}

Célkitüzés: A promiszkuitás és a megbízható fogamzásgátlás hiánya növeli a szexuálisan úton átvihető betegségek előfordulási valószínűségét és a nem kívánt terhességek létrejöttének kockázatát. Az egyetemi hallgatók fokozottabban veszélyeztetettek ebből a szempontból. Célul tüztük ki, hogy felmérni az egyetemisták megbízható fogamzásgátlásra és nemi úton terjedő betegségekre vonatkozó ismereteit és a szexuális egészségnevelés hatékonyságát. Anyag és módszer: Az ismeretek felmérésére anonim, önkitöltős kérdőíves felmérést végeztünk a Szegedi Tudományegyetem hallgatóinak randomizált mintáján (N=474) 2009 és 2011 között.

Eredmények: A kortárs segítők által tartott iskolai reproduktív egészségnevelő órákon elhangzottakat $62,1 \%$ tartotta megbízhatónak és hitelesnek, 12,3\% pedig kevésbé megbízhatónak ítélte. Mindössze a válaszadók 25,6\%-a nevezte meg az iskolai felvilágosítást irrelevánsnak. A nemek megoszlását tekintve abban a csoportban, akik megbízhatónak tartják, a kortárs segítő egészségfejlesztést, szignifikánsan több a lány (69,3\% vs. 46,6 \% p=0,001), szignifikánsan kevesebben laknak városban $(83,6 \%$ vs. 94,8 \% p=0,025). Szignifikánsan többen tudták $(79,5 \%$ illetve $63,9 \%$ p=0,02), hogy a Candida fertőzés átvihető szexuális érintkezés útján az iskolai felvilágosító órát fontosnak tartók közül megbízhatónak. A válaszadók túlnyomó többsége a szexuális kérdésekkel kapcsolatban a médiából szerezte ismereteit.

Következtetések: Azok a fiatalok, akik a kortárs segítők előadásait megbízhatónak tartják, a Candida betegségröl szignifikánsan tájékozottabbak.

\section{KULCSSZAVAK}

Egyetemi hallgatók, nemi úton terjedő infekciók, megbízható fogamzásgátló módszerek 
Iván Devosa, Zoltán Kozinszky M.D., Ph.D., Melinda Vanya M.D., Alice dombi Fáyné Ph.D., Katalin Barabás M.D., Ph.D.

KNOWLEDGE OF RELIABLE CONTRACEPTIVE

METHODS AND SEXUALLY TRANSMITTED

INFECTIONS AMONG THE UNIVERSITY STUDENTS

IN SZEGED

\begin{abstract}
Introduction: Promiscuity and lack of use of reliable contraceptive methods increase the probability of sexually transmitted diseases and the risk of unwanted pregnancies, which are quite common among university students.

Aim: The aim of the study was to assess the knowledge of university students about reliable contraceptive methods and sexually transmitted diseases, and to assess the effectiveness of the sexual health education in secondary schools, with specific focus on the education held by peers.
\end{abstract}

Method: An anonymous, self-administered questionnaire survey was carried out in a randomized sample of students at the University of Szeged $(n=472,298$ women and 174 men, average age 21 years) between 2009 and 2011. Results: 62.1\% of the respondents declared that reproductive health education lessons in high schools held by peers were reliable and authentic source of information, $12.3 \%$ considered as a less reliable source, and $25.6 \%$ defined the school health education as irrelevant source. Among those, who considered the health education held by peers as a reliable source, there were significantly more females $(69.3 \%$ vs. $46.6 \%, p=0.001)$, significantly fewer lived in cities $(83.6 \%$ vs. $94.8 \%, p=0.025)$, and significantly more responders knew that Candida infection can be transmitted through sexual intercourse $(79.5 \%$ versus $63.9 \%, \mathrm{p}=0.02)$ as compared to those who did not consider health education held by peers as a reliable source. The majority of respondents obtained knowledge about sexual issues from the mass media.

Conclusions: Young people who considered health educating programs reliable were significantly better informed about Candida disease. Orv. Hetil., 2016, 157(14), 539-546. 


\section{KEYWORDS}

university students, sexually transmitted diseases, sexual risk taking behaviour, contraceptive methods

\section{BEVEZETÉS}

$\mathrm{Az}$ iskolai szexuális nevelés felkészíti a fiatalokat a szerelem és a párkapcsolat nehézségeire, célja hogy eloszlassa kétségeket is a bizonytalanságból adódó kétségeket, valamint a hatékony egészségnevelés csökkenti a magas kockázatú szexuális magatartás előfordulását. A magas kockázatú szexuális viselkedés következményei a nem kívánt terhességek magas száma valamint a szexuális úton terjedő betegségek gyakoribb előfordulása. Magyarországon a 15-24 évesek körében az 1000 megfelelő korú női lakosság körében a terhesség megszakítások száma 43,7-ről (1995) 26,3-ra (2009)[1]. Ezzel szemben a Clamydia trachomatis fertőzések legnagyobb arányú előfordulása is erre az életkorra volt tehető 1995-ben $(7,8 \%)$ és 2006-ban $(10,0 \%)$ is, amely enyhe emelkedést mutat a leggyakoribb nemi úton terjedő betegség (STI) tekintve [2;3]. A Clamydia trachomatis fertőzés leginkább a fogamzásgátló tabletta és a kondom kombinált használatával áll összefüggésben a tizenévesek kontraceptív módszereit tekintve, ami valószínüsíti, hogy ebben a korcsoportban a fogamzásgátló módszerek ezen kombinációja segíti elő a leginkább a promiszkuitást és vélhetően nem minden alkalommal használnak kondomot a fiatalok [4].

Jelen vizsgálatunkban a fiatalok ismereteit térképeztük fel megbízható fogamzásgátlási eszközökről, szexuális úton terjedő betegségekről valamint az egészségnevelés hatékonyságát mértük fel a Szegedi Tudományegyetem hallgatói körében.

\section{ANYAG ÉS MÓDSZER}

A nemi élet jellemzőire és a szexuális ismeretekre vonatkozó kérdőíves felmérés résztvevőinek kiválasztása random módon történt a Szegedi Tudományegyetem több karának hallgatói közül. Koruk és lakóhelyük szerint az egyetemi hallgatók nyilvántartó rendszeréből a saját fejlesztésü R4A randomizációs szoftver segítségével történt a 472 fő kiválasztása 2009-2011-ben. Mindössze 9,3\% utasította el a részvételt. 298 lány és 174 fiú került a mintába. A felmért személyek életkora 20-22 év volt.

Az önkitöltős kérdőív kérdéseit a szakirodalmi adatok alapján a szerzők állították össze a fentebb megfogalmazott tudományos célnak megfelelően. A kérdőív megbízhatóságát a 
belső konzisztenciát mutató Cronbach- $\alpha$ a teljes mérőeszközre vonatkozva 0,887 volt, ami megfelelőnek mondható.

A kérdőív szocio-demográfiai illetve a fogamzásgátlási és szexuális szokásokra vonatkozó kérdéseket foglal magába egyszeres vagy többszörös válaszadási lehetőséggel. A statisztikai összehasonlítások folytonos változók esetén Mann-Whitney-féle U-próbával, míg kategorikus változók esetén az $\chi^{2}$-próbával történtek. Logisztikus regressziót használtunk a szexuális kockázatvállaló viselkedés többváltozós elemzésére a lépcsőzetes beillesztés módszerével, amelynek során az egyes kockázati tényezőket egyenként vizsgáltuk a modellt fokozatosan felépítve. A végső, legrobusztusabb modell került prezentálásra, melyben nem szerepeltek zavarótényezők illetve az összes determináló faktor szignifikáns volt. A kategorikus változók összehasonlításakor a 95\%-os konfidencia intervallumot illetve az esélyhányadost (odds rátát) is feltüntettuik. A statisztikai próbák esetében a $\mathrm{p}=0,05$-öt tekintettünk a szignifikancia határának.

\section{Eredmények}

Szocio-demográfiai adatok alapján vizsgáltuk az iskolai egészségfejlesztés fontosságának különbségeit az általunk létrehozott két csoportban (1. táblázat). Ezen populáción belül két vizsgálati csoportot képeztünk: a szexuális egészségfejlesztésre vonatkozó információforrásokat nagyon megbízhatónak tartja (n=293), illetve a másik csoport, amely tagjai a szexuális egészségfejlesztésre vonatkozó információforrásokat kevésbé megbízhatónak tartja $(\mathrm{n}=58)$.

A nemek megoszlását tekintve abban a csoportban, akik megbízhatónak tartják, a kortárssegítő egészségfejlesztést, szignifikánsan több a lány $(69,3 \%$ vs. 46,6 \% p p=0,001), szignifikánsan kevesebben laknak városban $(83,6 \%$ vs. 94,8 \% p=0,025). A testvérek száma, illetve a vallásosság nem jelentett szignifikáns különbséget a két csoport között. Azok, akik megbízhatónak tartották az iskolai felvilágosítást, nem különböztek szignifikáns módon életkor alapján azoktól, akik nem tartották teljesen megfelelő információforrásnak.

\section{1. táblázat. Szociodemográfiai adatok}

\begin{tabular}{lcccc}
\hline \multirow{2}{*}{$\begin{array}{c}\text { Szocio- } \\
\text { demográfiai }\end{array}$} & $\begin{array}{c}\text { A kortárssegitószségfejlesztést } \\
\text { megbizhatónak }\end{array}$ & $\begin{array}{c}\text { A kortárssegítő } \\
\text { egésségfejlesztést }\end{array}$ & p-érték & OR \\
& nem tartja & & $(95 \%$ \\
\hline
\end{tabular}




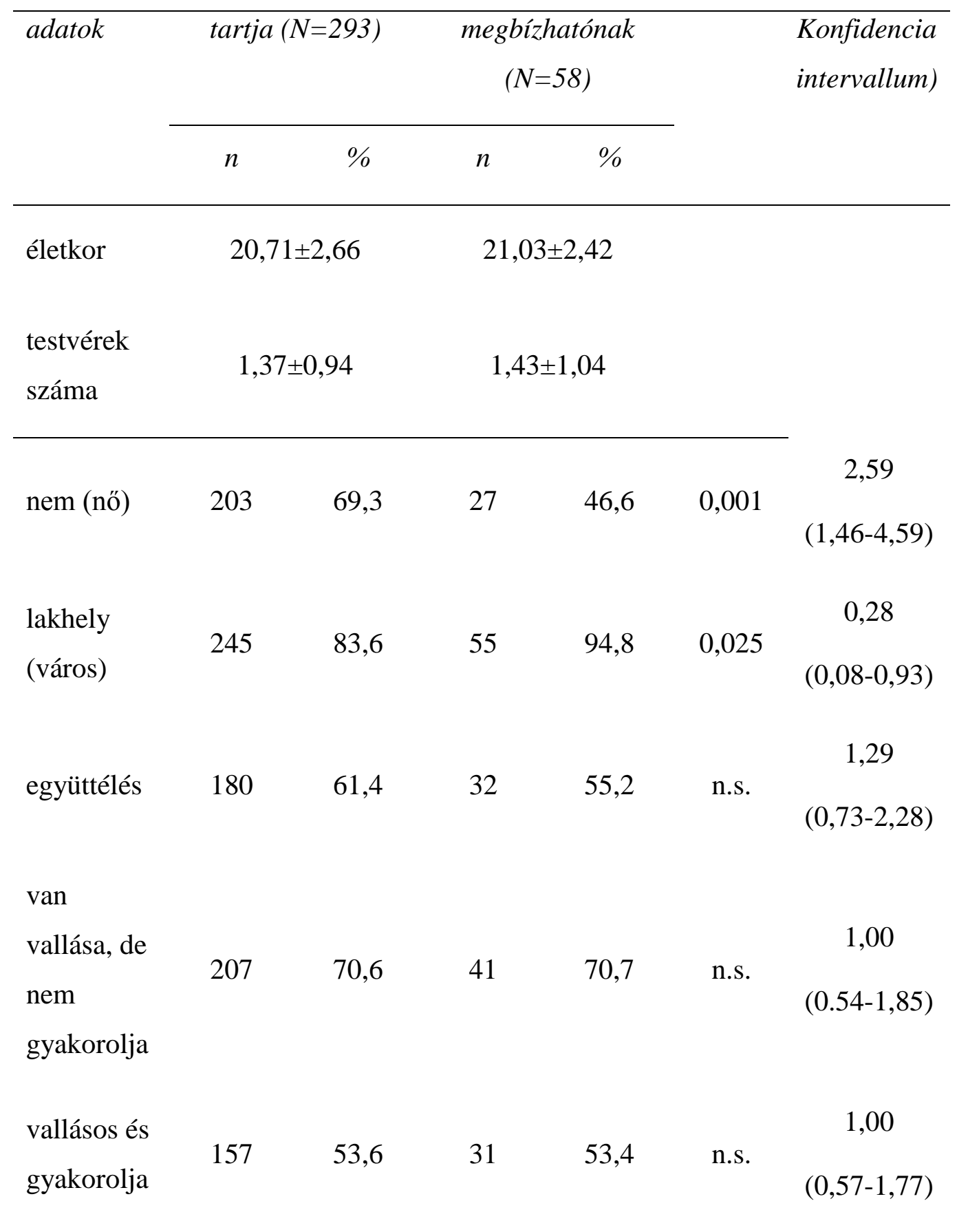

Magas arányban (57,6\%) tartják megbízhatónak az egészségügyi dolgozók által nyújtott információt, továbbá a család (57,4\%) és az internet (57,0\%), a barátok, a kortársak $(44,1 \%)$, az újságok (40.9\%) által szolgáltatott információt a kontracepcióra és a nemi életre.

A további vizsgálatainkban azokat hasonlítottuk össze, akik megbízhatónak (n=293) illetve kevésbé megbízhatónak $(n=58)$ tartották az iskolai egészségnevelő tevékenységet (3. táblázat). 
A megkérdezettek szexuális egészségére vonatkozóan összesen 3 információforrást jelölhettek meg a legfontosabbnak. A kortárssegítők által tartott iskolai reproduktív egészségnevelő órákon elhangzottakat $62,1 \%$ tartotta megbízhatónak és hitelesnek, 12,3\% pedig kevésbé megbízhatónak ítélte az ebből a forrásból kapott információkat. Mindössze a válaszadók 25,6\%-a nevezte meg az iskolai felvilágosítást irrelevánsnak (3. táblázat).

3. táblázat. A szexuális egészségfejlesztésre vonatkozó információforrások megbízhatóságának megoszlása

\begin{tabular}{|c|c|c|c|c|c|c|}
\hline \multirow{3}{*}{$\begin{array}{l}\text { Szexuális egészségre } \\
\text { vonatkozó } \\
\text { információforrás } \\
(N=472)\end{array}$} & \multirow{2}{*}{\multicolumn{2}{|c|}{ Nagyon }} & \multirow{2}{*}{\multicolumn{2}{|c|}{ Kevésbé }} & \multirow{2}{*}{\multicolumn{2}{|c|}{$\begin{array}{c}\text { Nem tekintette } \\
\text { fontosnak a kapott } \\
\text { információt }\end{array}$}} \\
\hline & & & & & & \\
\hline & $n$ & $\%$ & $n$ & $\%$ & $n$ & $\%$ \\
\hline $\begin{array}{l}\text { iskolai } \\
\text { egészségnevelés }\end{array}$ & 293 & 62,1 & 58 & 12,3 & 121 & 25,6 \\
\hline $\begin{array}{l}\text { egészségügyi } \\
\text { dolgozó, orvos }\end{array}$ & 272 & 57,6 & 7 & 1,5 & 193 & 40,9 \\
\hline család & 271 & 57,4 & 50 & 10,6 & 151 & 32,0 \\
\hline internet & 269 & 57,0 & 126 & 26,7 & 77 & 16,3 \\
\hline tankönyv & 265 & 56,1 & 11 & 2,3 & 196 & 41,5 \\
\hline barátok, kortársak & 208 & 44,1 & 112 & 23,7 & 152 & 32,2 \\
\hline újságok & 193 & 40,9 & 151 & 32,0 & 128 & 27,1 \\
\hline televízió & 172 & 36,4 & 155 & 32,8 & 145 & 30,7 \\
\hline rádió & 114 & 24,2 & 175 & 37,1 & 183 & 38,8 \\
\hline társadalmi szervezet & 89 & 18,9 & 174 & 36,9 & 209 & 44,3 \\
\hline vallási közösség & 53 & 11,2 & 214 & 45,3 & 205 & 43,4 \\
\hline
\end{tabular}


brosúrák,

tájékoztató füzetek

A következő táblázatban (4. táblázat) azt mutatjuk be, hogy milyenek a szexuális attitüdjei azoknak, akik a kortárssegítő egészségfejlesztést megbízhatónak tartják, illetve azoknak, akik nem tartják megbízhatónak. A két csoport attitüdje többnyire nem tér el jelentősen a különféle szexuális aktivitás megítélésében, csak a nudizmus $(p=0,005)$ és a sztriptíz bárba járás tekintetében voltak szignifikánsan konzervatívabbak $(\mathrm{p}=0,007)$ és kevésbé elfogadóak azok, akik megbízhatóbbnak ítélték az iskolai reproduktív egészségnevelési órákon elhangzottakat.

\section{4. táblázat. Szexuális attitüdre vonatkozó kérdések}

\begin{tabular}{|c|c|c|c|c|c|c|}
\hline \multirow[t]{2}{*}{$\begin{array}{l}\text { Nem tartja } \\
\text { elfogadhatónak }\end{array}$} & \multicolumn{2}{|c|}{$\begin{array}{c}\text { A kortárssegitö } \\
\text { egészségfejlesztést } \\
\text { megbizhatónak } \\
\text { tartja }(N=293)\end{array}$} & \multicolumn{2}{|c|}{$\begin{array}{c}\text { A kortárssegitő } \\
\text { egészségfejleszt } \\
\text { ést nem tartja } \\
\text { megbízhatónak } \\
(N=58)\end{array}$} & \multirow[t]{2}{*}{ p-érték } & \multirow[t]{2}{*}{$\begin{array}{c}\text { OR } \\
(95 \% \\
\text { Konfidencia } \\
\text { intervallum) }\end{array}$} \\
\hline & $\mathrm{n}$ & $\%$ & $\mathrm{n}$ & $\%$ & & \\
\hline poliandriát & 244 & 83,3 & 44 & 75,9 & n.s. & $\begin{array}{c}1,58 \\
(0,81-3,11)\end{array}$ \\
\hline megcsalást & 239 & 81,6 & 45 & 77,6 & n.s. & $\begin{array}{c}1,28 \\
(0,65-2,53)\end{array}$ \\
\hline poligámiát & 233 & 79,5 & 42 & 72,4 & n.s. & $\begin{array}{c}1,48 \\
(0,78-2,81)\end{array}$ \\
\hline prostitúciót & 190 & 64,8 & 31 & 53,4 & n.s. & $\begin{array}{c}1,61 \\
(0,91-2,84)\end{array}$ \\
\hline
\end{tabular}




\begin{tabular}{|c|c|c|c|c|c|c|}
\hline csoportszexet & 166 & 56,7 & 32 & 55,2 & n.s. & $\begin{array}{c}1,06 \\
(0,60-1,87)\end{array}$ \\
\hline homoszexualitás & 140 & 47,8 & 31 & 53,4 & n.s. & $\begin{array}{c}0,80 \\
(0,45-1,40)\end{array}$ \\
\hline házasságot & 105 & 35,8 & 24 & 41,4 & n.s. & $\begin{array}{c}0,79 \\
(0,44-1,41)\end{array}$ \\
\hline pornográfiát & 66 & 22,5 & 7 & 12,1 & n.s. & $\begin{array}{c}2,12 \\
(0,92-4,89)\end{array}$ \\
\hline nudizmust & 47 & 23,2 & 4 & 6,9 & 0,005 & $\begin{array}{c}4,07 \\
(1,4-11,82)\end{array}$ \\
\hline sztriptízt & 44 & 22,8 & 4 & 6,9 & 0,007 & $\begin{array}{c}3,99 \\
(1,37-11,62)\end{array}$ \\
\hline $\begin{array}{l}\text { házasság előtti } \\
\text { szexet }\end{array}$ & 6 & 2,0 & 1 & 1,7 & n.s. & $\begin{array}{c}1,19 \\
(0,14-10,09)\end{array}$ \\
\hline maszturbációt & 5 & 1,7 & 2 & 3,4 & n.s. & $\begin{array}{c}0,49 \\
(0,09-2,57)\end{array}$ \\
\hline
\end{tabular}

Fontosnak véltük annak megismerését, hogy a fiatalok kihez fordulnak, hogy a szexuális téren felmerülő kérdéseiket megválaszolják, illetve ha valamilyen szexuális problémájuk van. A szexualitásra és a fogamzásgátlásra vonatkozó információk megszerzésében a két csoport tagjai szintén hasonlóan leginkább az internetre (56,9\% illetve $72,7 \%$ ) támaszkodtak, és onnan szereztek jelentős mennyiségü és minőségü információt (5. táblázat).

A szexuális problémájukat az iskolai felvilágosítást nem megbízhatónak nevező válaszadók leginkább a partnerükkel, a barátaikkal és a családtagjaikkal $(91,4 \%)$ beszélik meg, míg az iskolai felvilágosító órákat fontosnak tartók, ugyanezeket a csatornákat használják a nemi problémáik megbeszélésére, jelentősen kiegészítve nőgyógyász/urológus szakember bevonásával is. 
5. táblázat. Szexuális információforrások az iskolai egészségfejlesztő órát hatékonynak illetve nem hatékonynak megnevezők körében

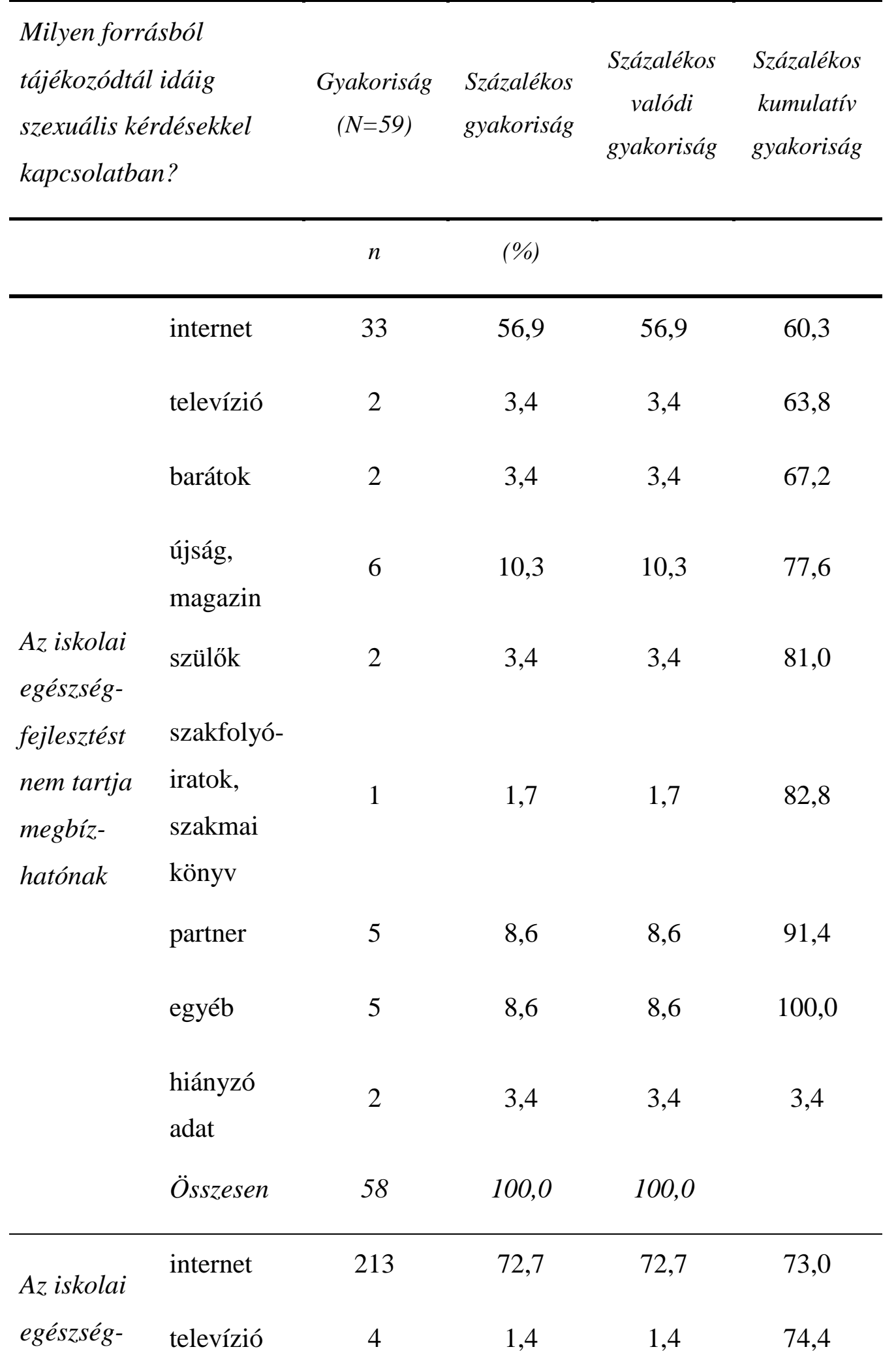




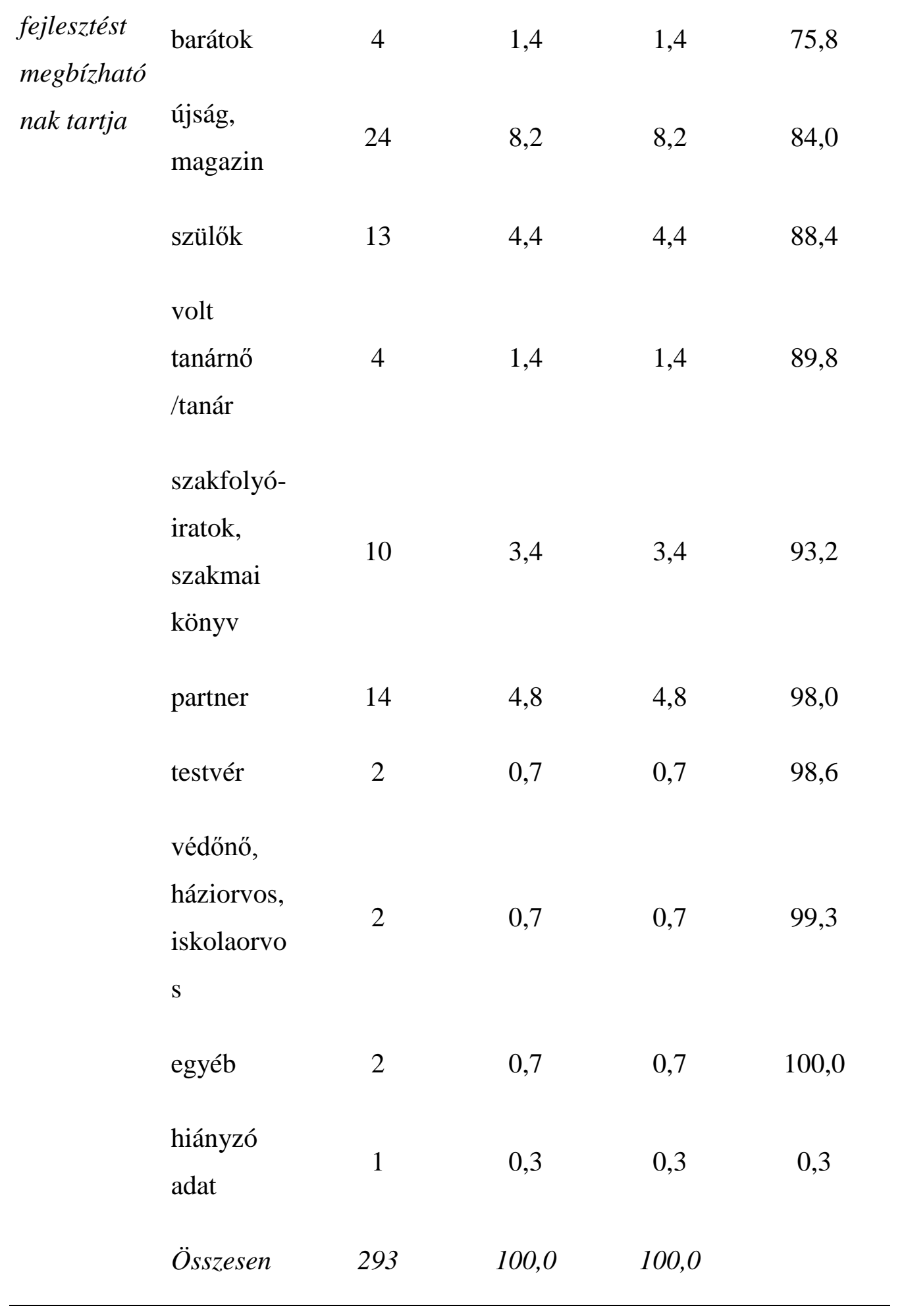

Mindkét csoport jellemzően úgy gondolja, hogy a nemi és fogamzásgátlásra vonatkozó felvilágosítás alappillére a család. Mint fontos egészségnevelő fórum az egészségfejlesztőket 10,3\% illetve 13,0\% arányban nevezték meg. Ezért is fontos, hogy olyan egészségfejlesztő szakemberek álljanak a tanulók rendelkezésére, akik kellően felkészültek a kérdésekre, és akikben megbízhatnak. A hatékony egészségnevelői munka segíthet, hogy minél későbbre 
tolódjon az első szexuális élmény ideje, illetve, hogy a hallgatók tudtára adjuk, hogy már az első közösülés alkalmával is megfertőződhetnek, ha nem védekeznek megfelelően. [6] A tizenévesek érdeklődésének középpontjában áll a szexualitás, a hiányos és sokszor téves ismereteiket mégis elegendőnek ítélik, pedig kevés információjuk van, vagy egyáltalán nem rendelkeznek ismerettel a fogamzás természetes módjáról, a fogamzásgátlásról és a szexuális úton terjedő betegségekről (Simich és Fábián, 2010). A nemi úton terjedő betegségek közül azokat, amelyeket a médiában nagy érdeklődés övez (HIV, gonorrhoea, szifilisz) illetve az elterjedtebbek közé tartoznak (Chlamydia, Hüvelygomba, Genitális herpesz, Human Papilloma Vírus) azokat viszonylag jól ismerik mindkét csoport tagjai, viszont a ritka megbetegedéseket (LGV, Donovanosis, Trichomonas fertőzést) kevesen ismerték. A szifilisz a legismertebb betegség mindkét csoportban (97,6\% illetve 96,6\%). Egyedül a Candida fertőzést ismerik (79,5\% illetve 63,9\%) szignifikáns módon többen az iskolai felvilágosító órát fontosnak tartók $(\mathrm{p}=0,02)$. Az STI-k nemi érintkezés útján történő átvihetőségének ismeretében is hasonló eredményt adott a következő táblázat (9. táblázat).

\section{9. táblázat. A nemi úton terjedő betegségek ismerete}

\begin{tabular}{|c|c|c|c|c|c|c|}
\hline \multirow[t]{2}{*}{ Ismeri a(z) } & \multicolumn{2}{|c|}{$\begin{array}{c}\text { A kortárssegitö } \\
\text { egészség- } \\
\text { fejlesztést } \\
\text { megbízhatónak } \\
\text { tartja }(N=293)\end{array}$} & \multicolumn{2}{|c|}{$\begin{array}{c}\text { A kortárssegitö } \\
\text { egészség- } \\
\text { fejlesztést nem } \\
\text { tartja } \\
\text { megbizhatónak } \\
(N=58)\end{array}$} & \multirow[t]{2}{*}{ p-érték } & \multirow[t]{2}{*}{$\begin{array}{c}\text { OR } \\
(95 \% \\
\text { Konfidencia } \\
\text { intervallum })\end{array}$} \\
\hline & $n$ & $\%$ & $n$ & $\%$ & & \\
\hline $\begin{array}{l}\text { Bakteriális } \\
\text { vaginózist }\end{array}$ & 108 & 36,9 & 21 & 36,2 & n.s. & $\begin{array}{c}1,03 \\
(0,57-1,85)\end{array}$ \\
\hline Candidát & 233 & 79,5 & 37 & 63,8 & 0,02 & $\begin{array}{c}2,20 \\
(1,20-4,04)\end{array}$ \\
\hline Chlamydiát & 187 & 63,8 & 33 & 56,9 & n.s. & $\begin{array}{c}1,34 \\
(0,76-2,37)\end{array}$ \\
\hline
\end{tabular}




\begin{tabular}{|c|c|c|c|c|c|c|}
\hline Condylomát & 57 & 19,5 & 12 & 20,7 & n.s. & $\begin{array}{c}0,93 \\
(0,46-1,86)\end{array}$ \\
\hline Donovanosist & 44 & 15,0 & 12 & 20,7 & n.s. & $\begin{array}{c}0,68 \\
(0,33-1,38)\end{array}$ \\
\hline $\begin{array}{l}\text { Genitális } \\
\text { herpest }\end{array}$ & 274 & 93,5 & 55 & 94,8 & n.s. & $\begin{array}{c}0,79 \\
(0,22-2,75)\end{array}$ \\
\hline Genital warts-ot & 214 & 73,0 & 40 & 69,0 & n.s. & $\begin{array}{c}1,22 \\
(0,66-2,25)\end{array}$ \\
\hline Gonorrhoeat & 250 & 85,3 & 50 & 86,2 & n.s. & $\begin{array}{c}0,93 \\
(0,41-2,10)\end{array}$ \\
\hline HIV-fertőzést & 293 & 100 & 57 & 98,3 & n.s. & $\begin{array}{c}1,02 \\
(0,98-1,05)\end{array}$ \\
\hline HPV-fertőzést & 226 & 77,1 & 40 & 69,0 & n.s. & $\begin{array}{c}1,52 \\
(0,82-2,82)\end{array}$ \\
\hline LGV-t & 49 & 16,7 & 12 & 20,7 & n.s. & $\begin{array}{c}0,77 \\
(0,38-1,56)\end{array}$ \\
\hline $\begin{array}{l}\text { Kismedencei } \\
\text { gyulladást }\end{array}$ & 171 & 58,4 & 35 & 60,3 & n.s. & $\begin{array}{c}0,92 \\
(0,52-1,64)\end{array}$ \\
\hline Szifiliszt & 286 & 97,6 & 56 & 96,6 & n.s. & $\begin{array}{c}1,46 \\
(0,29-7,21)\end{array}$ \\
\hline Trichomoniasist & 76 & 25,9 & 17 & 29,3 & n.s. & $\begin{array}{c}0,85 \\
(0,45-1,58)\end{array}$ \\
\hline Ulcert & 254 & 86,7 & 53 & 91,4 & n.s. & $\begin{array}{c}0,62 \\
(0.23-1,63)\end{array}$ \\
\hline
\end{tabular}


Az elterjedtebb illetve ismertebb betegségek esetében köztudottabb volt az iskolai egészségfejlesztést fontosnak tartó csoport tagjai között, hogy azok átvihetők hüvelyi úton történő közösüléssel. A HIV-fertőzésről - köszönhetően a médiának - szinte mindenki $(96,6 \%$ és 98,3\%) tudta, hogy nemi érintkezés útján is terjed (9. táblázat).

11. táblázat. A STI-k ellen legmegbízhatóbbnak tartott módszerek megoszlása

\begin{tabular}{|c|c|c|c|c|c|}
\hline \multicolumn{2}{|c|}{$\begin{array}{l}\text { LEGmegbízhatóbbnak vélt } \\
\text { módszerek az STI-k ellen }\end{array}$} & Gyakoriság & $\begin{array}{l}\text { Százalékos } \\
\text { gyakoriság }\end{array}$ & $\begin{array}{l}\text { Százalékos } \\
\text { valódi } \\
\text { gyakoriság }\end{array}$ & $\begin{array}{l}\text { Százalékos } \\
\text { kumulatív } \\
\text { gyakoriság }\end{array}$ \\
\hline & $\begin{array}{l}\text { szerinte nincs } \\
\text { ilyen módszer }\end{array}$ & 15 & 25,9 & 25,9 & 25,9 \\
\hline & óvszer & 31 & 53,4 & 53,4 & 79,3 \\
\hline$A$ & $\begin{array}{l}\text { óvszer és } \\
\text { higiénia }\end{array}$ & 1 & 1,7 & 1,7 & 81,0 \\
\hline $\begin{array}{l}\text { kortárs- } \\
\text { segíto" }\end{array}$ & óvatosság & 1 & 1,7 & 1,7 & 82,8 \\
\hline $\begin{array}{l}\text { egészség- } \\
\text { fejlesztést }\end{array}$ & önmegtartóztatás & 2 & 3,4 & 3,4 & 86,2 \\
\hline $\begin{array}{l}\text { nem } \\
\text { tartja }\end{array}$ & $\begin{array}{l}\text { monogámia és } \\
\text { óvszer }\end{array}$ & 2 & 3,4 & 3,4 & 89,7 \\
\hline $\begin{array}{l}\text { megbiz- } \\
\text { hatónak }\end{array}$ & $\begin{array}{l}\text { óvszer és } \\
\text { fogamzásgátló }\end{array}$ & 4 & 6,9 & 6,9 & 96,6 \\
\hline & $\begin{array}{l}\text { többszörös } \\
\text { védekezés }\end{array}$ & 1 & 1,7 & 1,7 & 98,3 \\
\hline & fogamzásgátló & 1 & 1,7 & 1,7 & 100,0 \\
\hline & Összesen & 58 & 100,0 & 100,0 & \\
\hline$A$ & szerinte nincs & 69 & 23,5 & 23,5 & 23,5 \\
\hline
\end{tabular}




\begin{tabular}{|c|c|c|c|c|c|}
\hline kortárs- & ilyen módszer & & & & \\
\hline $\begin{array}{l}\text { segilo } \\
\text { egészség- }\end{array}$ & óvszer & 186 & 63,5 & 63,5 & 87,0 \\
\hline \multirow{2}{*}{$\begin{array}{l}\text { fejlesztést } \\
\text { megbíz- }\end{array}$} & óvatosság & 1 & 0,3 & 0,3 & 87,4 \\
\hline & & & & & \\
\hline hatónak & önmegtartóztatás & 9 & 3,1 & 3,1 & 90,4 \\
\hline \multirow[t]{14}{*}{ tartja } & monogámia & 6 & 2,0 & 2,0 & 92,5 \\
\hline & $\begin{array}{l}\text { monogámia és } \\
\text { óvszer }\end{array}$ & 9 & 3,1 & 3,1 & 95,6 \\
\hline & $\begin{array}{l}\text { óvszer és } \\
\text { fogamzásgátló }\end{array}$ & 4 & 1,4 & 1,4 & 96,9 \\
\hline & $\begin{array}{l}\text { higiénia és } \\
\text { orvosi vizsgálat }\end{array}$ & 1 & 0,3 & 0,3 & 97,3 \\
\hline & monogámia & & & & \\
\hline & vagy & 2 & 0,7 & 0,7 & 98,0 \\
\hline & önmegtartóztatás & & & & \\
\hline & orvosi vizsgálat & 2 & 0,7 & 0,7 & 98,6 \\
\hline & fogamzásgátló & & & & \\
\hline & és orvosi & 1 & 0,3 & 0,3 & 99,0 \\
\hline & vizsgálat & & & & \\
\hline & fogamzásgátló & 2 & 0,7 & 0,7 & 99,7 \\
\hline & $\begin{array}{l}\text { óvszer és } \\
\text { pesszárium }\end{array}$ & 1 & 0,3 & 0,3 & 100,0 \\
\hline & Összesen & 293 & 100,0 & 100,0 & \\
\hline
\end{tabular}

Az óvszerhasználat kulcskérdés a szexuális úton terjedő betegségek megelőzésében. Ezért célszerü ezt a kérdést jobban megvizsgálni, hogy vajon van-e különbség a két vizsgált 
csoportban atekintetben, hogy mennyire gondolják a hallgatók, hogy a kondom nyújtja a legmegbízhatóbb védelmet a nemi betegségekkel szemben (11. táblázat). A táblázat eredményei nem mutatnak szignifikáns eltérést a két csoport véleménye között

A fogamzásgátló tablettát a hallgatók megbízhatóbb fogamzásgátló eszköznek tartják, mint az óvszert. Az óvszert azonban a fogamzásgátló tabletta mellett is célszerü használni, hiszen gondolni kell a nemi betegségekre is.

A kondomra vonatkozó kérdések között csak egy esetben volt statisztikailag értékelhető különbség ( $\mathrm{p}=0,03)$, többen mondták, hogy azért nem használják az óvszert, mert „nem szexis”, azok között, akik az iskolai felvilágosítást nem tartják megbízhatónak (31. táblázat).

A legtöbben azért nem alkalmaztak kondomot, mert más fogamzásgátló eszközzel védekeztek, illetve egyéb szubjektív vélemény volt, hogy csökkenti az érzékiséget, ezért a párkapcsolatban vagy a fiú nem óhajtja használni, vagy bizalom áll fent a partnerek között.

Az óvszerhasználat ellen szólt, hogy kényelmetlen volt mindkét csoport számára. Sajnos ez ellen a tény ellen nem sok mindent lehet tenni, bár az óvszergyártók próbálnak minél vékonyabb és finomabb anyagból óvszert készíteni.

Azonban az óvszer többi jellemzője csak elenyészően befolyásolta a két vizsgált csoport tagjait.

Az egészségnevelők feladata felhívni a figyelmet arra, hogy ürügyet könnyü találni arra, hogy miért ne használják a partnerek az együttlét során a kondomot, de a használata melletti előnyökre kell helyezni a hangsúlyt, hogy egyszerre véd a nem kívánt terhesség és a nemi betegségek ellen, illetve a többi fogamzásgátló módszerhez képest könnyebb és olcsóbb is a használata.

\section{Disszkusszió}

A legelső szexuális ismeretekre a gyerekek többnyire otthon tesznek szert a szülők, a rokonok vagy az ismerősök szándékos illetve nem szándékos tájékoztatása révén. Ezt a szerepet később az iskola veszi át. Ehhez megfelelő szexuálpedagógiai szakemberekre, egészségnevelőkre és átfogó szexuális nevelésre van szükség (Szilágyi, 2011).

A szexuális nevelés során információt nyújtunk a hallgatóknak:

- a nemi élettel kapcsolatos testi folyamatok; pozitív hatásai; 
- az egyéni pszichoszexuális fejlődésről;

- a terhességről és a magzati életről, az abortuszról;

- a különböző szexuális életstílusokról;

- a fogamzásgátlók szakszerü használatáról;

- a nemi úton terjedő betegségekről és megelőzésükről (Szilágyi, 2011).

Az iskolai szexuális nevelés néhány kezdeményezéstől eltekintve a magyar iskolákban egészen napjainkig hiányzik. Időnként meghívnak egy egészségügyi szakembert, hogy tartson felvilágosító előadást a tanulóknak, de ez nem elég, mert nem tudja ellensúlyozni azokat a kedvezőtlen hatásokat, amelyekkel a fiatalok naponta találkoznak, például a televízión vagy az interneten keresztül (Szilágyi, 2003)

-A fogamzásgátlók közül a szakirodalom megbízhatónak a müvi meddővé tételt (méhkürt vagy ondóvezeték elvágása, elégetése, elkötése), a hormontartalmú módszereket, a hormont nem tartalmazó módszerek közül az intrauterin fogamzásgátló eszközt tartja. Meglepő, hogy a kondomot sokan megbízható módszernek tartják, azonban gyakran szakad el vagy csúszik le, és az alkalmazása viszonylag gyakran vezet következményes nem kívánt terhességhez (Kozinszky és mtsai, 2001). Mansour és munkatársai vizsgálata szerint a kondom egy köztes megbízhatóságú fogamzásgátló (Mansour, Inki és Gemzell-Danielsson, 2010).

Irodalomjegyzék

[1] Magyar demográfiai évkönyv 2010. Központi Statisztikai Hivatal, Budapest

[2] Deák J, Nagy E, Veréb I, Mészáros G, Kovács L, Nyári T, Berbik I. Prevalence of Chlamydia trachomatis infection in a low-risk population in Hungary. Sex. Transm. Dis., 1997; 24(9):538-42.

[3] Deák J. Determination of Chlamydia trachomatis infections in pregnant women by means of TaqMan PCR. In: Christiansen G, editor. Proceedings of the 6th meeting of the European society for chlamydia research. Aarhus, Denmark: Aarhus University. 2008; 193-4.

[4] Újházy A, Csaba A, Máté S, Papp Z, Sziller I. (2007): Chlamydia prevalence and correlates among female adolescents in Hungary. J Adolesc Health. 2007; 41(5): 513-5.

[5] Devosa Iván, Dr Kozinszky Zoltán, Dr Barabás Katalin Ellentmondások az iskolai reprodukciós egészségnevelésben. "AGTEDU 2013" - AGTEDU tudományos konferencia, Kecskemét 2013. 
[5] Jahn A, Bloemenkamp $K W$, Hannaford P, Olsen J, Da Silva M O, Temmerman M. Monitoring reproductive health in Europe-what are the best indicators of reproductive health? Human Reproduction. 2006; 21(9):2199-2200.

[6] Kozinszky Z, Boda K, Bartfai Gy. Determinants of abortion among women undergoing artificial termination of pregnancy. Eur J Contracept Reprod. Health Care. 2001; 6(3):145-52. [7] Imamura M, Tucker J, Hannaford P, Oliveira da Silva M, Astin M, Wyness L, Bloemenkamp KW M, Jahn A, Karro H, Olsen J, Temmerman M. Factors associated with teenage pregnancy in the European Union countries: a systematic review. European Journal of Public Health. 2007; 17(6): 630-636.

[8] Part K., Moreau C, Donati, S, Gissler M, Fronteira I, Karro H. Teenage pregnancies in the European Union in the context of legislation and youth sexual and reproductive health services. Acta obstetricia et gynecologica Scandinavica. 2013; 92(12): 1395-1406. 